\title{
MEMBACA GERAKAN ISLAM RADIKAL DAN DERADIKALISASI GERAKAN ISLAM
}

\author{
Muzayyin Ahyar \\ Universitas Islam Negeri (UIN) Sunan Kalijaga Yogyakarta \\ e-mail: muzayyin.ahyar@yahoo.com
}

\begin{abstract}
This study focussed on many radical Islamic movements in Solo as the objects of research, especially the islamic movements oftenly called as Tim Hisbah. Applying the approach of political sociology, this research will capture that phenomenons of religious radicalism are not merely problem of religious ideology, but also sociopolitical problem. Frammed by the social theories such as the theory of identity and social movements, included political opportunity structure, framing process, and the mobilizing structure this study showed that radicalism is an effort to establish identity by utilizing mass network (Muslim), mobilization, framing process, and advantaging political opportunities (democratic nature). In addition to relate to religious de-radicalization in Indonesia, this research argued that Islamic radicalism is not only a religious phenomenon that must be solved solely by de-radicalization of Islamic thought and ideology, but also a phenomenon that can be discussed by other sciences such as social, political and economic sciences.

Penelitian ini mengangkat gerakan Islam di Solo sebagai objek kajian, khususnya pada gerakan yang sering disebut Tim Hisbah. Dengan menggunakan pendekatan sosiologi politik, penelitian ini berusaha menangkap fenomena radikalisme agama bukan sepenuhnya gejala ideologi keagamaan, namun juga sebagai gejala sosialpolitik. Penelitian ini akan dipandu oleh teori-teori sosial seperti teori identitas dan gerakan sosial meliputi kesempatan politik (political opportunity structure), struktur pembingkaian (framing process), dan struktur mobilisasi (mobilizing structure). Temuan dari penelitian ini menggambarkan bahwa radikalisme adalah sebuah upaya membentuk identitas dengan menggunakan jejaring massa (Islam), dan memanfaatkan peluang politik (alam demokratis), mobilisasi dan proses pembingkaian. Dalam kaitannya dengan deradikalisasi, penelitian ini juga membahas bahwa radikalisme bukan hanya fenomena keagamaan, yang mana permasalahannya harus dipecahkan dengan deradikalisasi pemikiran dan ideologi Islam. Ia juga fenomena yang dapat dikaji melalui ilmu-ilmu lainnya seperti ilmu sosial, politik dan bahkan ekonomi.
\end{abstract}

Keywords: gerakan Islam radikal, Solo, teori gerakan sosial, teori identitas 


\section{A. Pendahuluan}

Gerakan Islamisme -yang tak jarang menggunakan jalan kekerasan-menjadi suatu fenomena yang menyeruak hadir dalam dunia internasional, terlebih setelah kejadian pesawat jet penumpang jenis Boeing, American Airlines Flight 77 menabrak gedung World Trade Center (WTC) dan pusat Departemen Pertahanan Amerika Serikat (Pentagon) pada 11 September 2001 silam. Amerika menengarai ini sebagai perbuatan teror yang dilakukan oleh al-Qaeda. Deklarasi dari Washington pun disiarkan melalui berbagai media internasional bahwa Gedung Putih melakukan kampanye besar menentang tindakan terorisme dengan semboyan "war against terrorism". Dalam beberapa pidatonya George W. Bush menegaskan tawarannya "every nation, and every region, now has a decision to make, either you are with us, or you are with the terrorist".

Pasca peristiwa tersebut berbagai reaksi yang dilakukan oleh beberapa gerakan Islamisme muncul di berbagai negara seperti peristiwa yang terjadi di stasiun kereta api Madrid, Spanyol, bom bunuh diri di Casablanca, Maroko, penyerangan atas perumahan warga asing di Riyadh Arab Saudi, dan termasuk di Indonesia. ${ }^{1}$ Paling tidak lima tahun ke depan semenjak peristiwa tersebut, dunia seakan melewati terowongan teror.

Di Indonesia, hadir pula serangkaian teror seperti bom Bali, 12 Oktober 2002, bom bunuh diri di Hotel JW Mariot pada Agustus 2003 dan beberapa kejadian lain dengan skala yang lebih rendah di beberapa wilayah seperti Kuningan, Cirebon, Klaten dan Solo. Gerakan Islam radikal juga muncul seperti Front Pembela Islam (FPI) yang kerap melakukan aksi sweeping di berbagai kota. Dalam skala nasional, Solo menjadi perhatian serius terhadap gerakan Islamisme radikal. Solo dipandang sebagai tempat tumbuh suburnya gerakan Islam yang radikal dengan karakteristik seperti vokal dalam menyuarakan anti kemaksiatan, penerapan syariat Islam, dan anti terhadap pemerintahan demokratis.

Fokus dari kajian ini adalah gerakan Islam radikal di Solo, dengan alasan bahwa kelompok-kelompok tersebut memiliki militansi yang cukup kuat dalam upaya menegakkan amar ma'rūf nahī munkar ${ }^{2}$ di Solo. Upaya yang dilakukan

\footnotetext{
${ }^{1}$ Majalah Tempo, edisi 7 Agustus 2005.

${ }^{2}$ Amar ma'rūfnahī munkar merupakan slogan yang selalu digunakan oleh kelompok Islam radikal untuk menunjukkan bahwa aksinya bernafaskan Islam dengan menyeru melakukan kebajikan dan mencegah kemungkaran atau tindakan yang melanggar kemaksiatan.
} 
adalah dengan cara mobilisasi masyarakat akar rumput yang terdiri para pemuda, dan bahkan juga para mantan preman. Gerakan-gerakan inilah yang seringkali melakukan transformasi kegiatan amar ma'rūf nahī munkar menjadi sebuah kegiatan yang lebih radikal seperti penyerangan unit-unit negara dan melakukan bom bunuh diri. ${ }^{3}$

Pemilihan lokasi penelitian di Solo dilakukan karena keunikannya. Di satu sisi, Solo adalah kota budaya di mana kebudayaan Jawa terkenal dengan sikap santun dan selalu bisa mengadaptasikan perbedaan dengan cara damai, toleran dan tidak radikal. Ini sejalan dengan pandangan beberapa ahli yang menyatakan bahwa budaya Jawa sejalan dengan misi Islam yang mengajarkan kemulian akhlak dan kesantunan. ${ }^{4}$ Di lain sisi, Solo dianggap sebagai pusat Islam Politik yang menginginkan perubahan total terhadap sistem pemerintahan dengan melakukan gerakan-gerakan perlawanan. Asumsi ini dikuatkan dengan maraknya kemunculan laskar-laskar jihad, dan juga beberapa kasus terorisme di Solo.

Radikalisme Islam di Solo tidak hanya identik dengan lembaga-lembaga yang didirikan oleh Abu Bakar Ba'asyir seperti Jama'ah Islamiyah (JI, 1993), Majelis Mujahidin Indonesia (MMI, 1999), atau Jama'ah Anshorut Tauhid (JAT, 2008), namun juga dikaitkan dengan laskar-laskar lokal di Solo seperti Front Pemuda Islam Surakarta (FPIS), Laskar Jundullah, Laskar Umat Islam Surakarta (LUIS), Hawariyyun hingga Tim Hisbah. Pertanyaan yang muncul kemudian adalah apakah fenomena gerakan Islam radikal ini hanya disebabkan karena adanya doktrin syariat Islam, yang kemudian membangkitkan semangat untuk memperjuangkan ayat-ayat jihad, tanpa ada kaitannya dengan kondisi sosial, politik atau ekonomi di suatu negara? apa yang sebenarnya melatar belakangi munculnya gerakan Islam radikal di Solo? Bagaimana gerakan ini bisa tumbuh subur? Serta sejauh mana fenomena ini dapat dikaitkan dengan kondisi sosial politik dan proses deradikalisasi agama yang saat ini berlaku di Indonesia?

Penjelasan publik terkait dengan pertanyaan-pertanyaan di atas yang tak jarang hadir pada diskusi-diskusi akademik adalah "teori konspirasi". Teori ini cenderung melihat fenomena semata mata sebagai permainan elit atau aparat politik untuk tujuan suatu privilege dan kekuasaan. Cara melihat seperti itu

\footnotetext{
${ }^{3}$ Dalam laporan ICG disebut mereka adalah kelompok Islam radikal yang bertransformasi menjadi kelompokpenebar teror.

${ }^{4}$ Baca: Simuh, Islam dan Pergumulan Budaya Jawa. (Jakarta: Teraju, 2003), Ahmad Khalil, Islam Jawa, Sufisme dalam Etika dan Tradisi Jawa, (Malang: UIN Malang Press, 2008).
} 
mengakibatkan munculnya pandangan bahwa fenomena Islam radikal hanyalah sebuah drama teatrikal yang telah memiliki skenario dari sutradara.

Kajian ini berupaya untuk melihat proses pembentukan identitas dan bagaimana identitas itu dipertahankan, dikomunikasikan dan disosialisasikan di dalam konteks sosial politik yang ada. Fokus kajiannya adalah gejala-gejala sosial masyarakat mengenai gerakan Islamisme atau Islam radikal. Bukan pada kajian dan pembuktian bahwa mereka benar-benar melakukan bom bunuh diri atau tidak. Adapun rumusan masalah yang ingin diungkap dalam penelitian ini adalah: mengapa dan dalam kondisi apa gerakan Islam radikal terbentuk? dan apa yang memotivasi anggota untuk ikut ke dalam gerakan?

Dengan menggunakan penelitian lapangan dengan jenis penelitian kualitatif, kajian ini menerapkan pendekatan sosiologi politik, Data-data primer diperoleh dari tempat aktivitas anggota gerakan Islam radikal, yaitu Kelurahan Semanggi Solo melalui wawancara bebas. Data sekunder juga digunakan untuk melengkapi kajian ini, baik yang berasal dari Solo maupun dari luar Solo, baik yang merupakan data elektronik ataupun cetak seperti penelitian lainnya, surat kabar, serta website resmi sebuah instansi atau lembaga. Data-data yang diperoleh dari hasil wawancara direduksi untuk mendapatkan data yang sesuai dengan fokus kajian. Adapun analisis data dilakukan dengan teori deradikalisasi agama

Penelitian ini diharapkan akan memberikan kontribusi dalam memperkaya kajian kelompok Islam radikal lokal yang berkembang di Indonesia dengan menghubungkan kondisi sosial politik, ekonomi dan budaya melalui teori gerakan sosial. Karenanya, penelitian ini penting untuk dilakukan sebagai upaya untuk menyandingkan ilmu-ilmu teologi Islam, khususnya teologi Islam radikal, dengan ilmu-ilmu sosial agar saling bertegur sapa.

\section{B. Solo, Identitas dan Teori Gerakan Sosial}

Penelitian yang mengambil objek radikalisme di Solo juga dilakukan oleh Muhammad Wildan. Wildan memfokuskan penelitiannya pada pemetaan gerakan-gerakan Islam yang tumbuh subur di Solo. Inti dari semua gerakan Islamisme radikal di Solo adalah pemurnian Islam. Semua gerakan mengaku Salafi, namun Wildan mencoba mengategorisasikan dua Salafi: Salafi murni (purity) dan Salafi jihadis. Dalam kerangka ini Wildan mencoba meminjam konsep Clifford Geertz mengenai trikotomi masyarakat Jawa untuk mendeskripsikan identitas masyarakat Jawa. 
Dalam kasus Solo, Wildan membagi tiga wilayah disekitar Solo sebagai unit analisis. Tiga wilayah tersebut merupakan bentukan pemerintah Hindia Belanda untuk memudahkan pemerintah dalam mengontrol aktivitas komunitas di Solo. Ketiga wilayah tersebut adalah Kauman, Laweyan, dan Pasar Kliwon. Kauman adalah komunitas eksklusif bagi para pegawai kerajaan. Kedekatan masyarakat Kauman dengan kerajaan membantu mereka untuk ikut ambil bagian dalam berbagai kegiatan bisnis masyarakat kelas menengah seperti berdagang batik dan merintis percetakan buku-buku Islam. Laweyan di sisi lain pada awalnya merupakan daerah yang penduduknya terdiri atas masyarakat abangan dari kelas menengah ke bawah. Dalam hal religiusitas, masyarakat Laweyan tidak sereligius masyarakat Kauman.

Pasar Kliwon memiliki ciri yang berbeda. Wilayah ini ditempati oleh masyarakat Arab yang memainkan peran perdagangan impor. Daerah ini seringkali dikontraskan dengan wilayahJebres yang banyak dihuni masyarakat Cina. Gerakan Islam radikal muncul disebabkan berbagai faktor, yaitu faktor sosial, budaya, ekonomi dan politik. Fenomena Islam radikal bisa digambarkan sebagai sebuah gerakan perlawanan yang terjadi karena kesenjangan sosial, ekonomi dan politik, terbentuk oleh kultur yang telah sekian lama sejak masa kolonial. Kurangnya pemimpin religius dan tradisional pada masyarakat Solo membentuk identitas baru para masyarakat abangan yang goyah. ${ }^{5}$

Kajian Muhammad Wildan di atas menjadi gerbang untuk masuk kepada penelitian selanjutnya mengenai gerakan Islam radikal di Indonesia. Untuk membahas gerakan Islam radikal pada era kontemporer, khususnya di Solo, penulis menggunakan teori gerakan sosial baru yang dikembangkan Sidney Tarrow. Dalam relasi gerakan dan kekuasaan, Tarrow menghadirkan tiga tekateki besar: pertama, kondisi apa yang membawa kekuatan pergerakan itu dapat muncul. Kedua, bagaimana dinamika pergerakan yang dapat melanggengkan kekuatan atas pergerakan tersebut. Ketiga, mengenai social outcomes atau dampak dan hasil dari gerakan sosial tersebut. ${ }^{6}$

\footnotetext{
5Muhammad Wildan, "Mapping Radical Islamism in Solo: a Study of the Proliferation of Radical Islamism in a Town in Central Java", dalam Martin van Bruinessen (ed.), Contemporary Developments In Indonesian Islam, Explaining The Conservative Turn, (Singapore: Institute of Southeast Asian Studies, 2013).

${ }^{6}$ Sidney Tarrow, Power in Movement; Social Movements, Collective Action and Politics, (Cambridge: Cambridge University Press, 1995), h. 1-2.
} 
Tiga teka-teki tersebut membawa Tarrow kepada beberapa teori untuk digali lebih lanjut. Tarrow menambahkan penjelasan tentang kesempatan politik bahwa sebuah gerakan sosial meningkat ketika berada dalam nuansa politik yang terbuka, mendapatkan dukungan sumberdaya dan berhasil memobilisasi sumber daya tersebut. Struktur kesempatan politik ini akan membantu sebuah penelitian gerakan sosial; bagaimana aktor-aktor gerakan itu melebur dalam sebuah aksi kolektif dan menjalin jaringan antara satu kelompok sosial dengan kelompok sosial lainnya untuk menyuarakan tujuannya. Inilah yang disebut Tarrow sebagai seizing and making opportunities, menggunakan dan membentuk kesempatan politik melalui aktor gerakan sosial. ${ }^{7}$

Para teoritisi gerakan sosial baru telah sependapat bahwa terdapat tiga struktur kunci penting ketika membahas sebuah gerakan sosial. Ketiga struktur kunci tersebut adalah struktur kesempatan politik (political opportunity structure), struktur pembingkaian (framing process), dan struktur mobilisasi (mobilizing structure). Struktur kesempatan politik dapat menjelaskan bahwa munculnya sebuah gerakan sosial seringkali dipicu oleh perubahan perubahan signifikan terhadap nuansa politik. Struktur ini merupakan pelengkap dari konsep pertentangan politik (contentious politics) yang menganggap aksi penentangan adalah aksi yang secara psikologis sangat tertekan, bersifat brutal dan irasional yang dipancing oleh provokator demi melawan sebuah rezim. ${ }^{8}$

\section{Solo: Jejak Gerakan Islam Radikal}

Kehadiran Gerakan Islam radikal dalam bentuk berbagai macam laskar Islam di Solo bukanlah sebuah fenomena baru. Asal-usulnya dapat ditelisik jauh ke belakang hingga masa kolonial Belanda, yaitu dengan adanya Serikat Dagang Islam (SDI) yang didirikan oleh H. Samanhudi pada tanggal 16 Oktober 1905, dan dalam masa selanjutnya organisasi ini berubah nama menjadi Serikat Islam (SI). Organisasi ini merupakan organisasi yang jelas-jelas menentang kolonial Belanda. Transisi iklim politik Indonesia dari era otoritarian ke arah politik demokrasi telah memunculkan konstalasi gerakan yang spesifik di Kota Solo. ${ }^{9}$

\footnotetext{
${ }^{7}$ Sidney Tarrow, Power in Movement; Social Movements..., h. 18.

${ }^{8}$ Quintan Wiktorowicz (ed.), Islamic Activism, a Social Movement Theory Approach, (Indiana: Indiana University Press, 2004), h. 9-10.

${ }^{9}$ Selengkapnya mengenai SDI dan SI baca Nasihin, Sarekat Islam Mencari Ideologi, (Yogyakarta: Pustaka Pelajar, 2012).
} 
Pada tahun-tahun berikutnya, Solo terus melahirkan gerakan Islam yang menentang pemerintah seperti gerakan Abdullah Sungkar dan Abu Bakar Ba'asyir yang memiliki visi menentang ideologi Pancasila sebagai asas tunggal. Pada awal-awal era reformasi, sangat banyak gerakan Islam radikal yang tumbuh di Solo sebagai respons terhadap situasi nasional seperti Laskar Hizbullah, Front Pemuda Islam Surakarta (FPIS), Laskar Jundullah, Laskar Umat Islam Surakarta (LUIS), Hawariyyun. Tim Hisbah adalah sebuah gerakan Islam radikal yang relatif paling muda di antara beberapa gerakan lainnya di Solo. Sebagai gambaran awal, berikut akan dipaparkan beberapa macam gerakan Islamisme di Solo dari era pra kemerdekaan hingga era Orde Baru sebagai bahan analisis kemunculan dan menjamurnya laskar-laskar Islam pada era reformasi dan di masa demokratisasi di Indonesia.

\section{Pra Kemerdekaan: Kasus Sarekat Dagang Islam (SDI)}

Sarekat Dagang Islam yang didirikan oleh H. Samanhudi pada 16 Oktober 1905. Pendirian SDI merupakan sebuah respons kultural akibat kesenjangan sosial-ekonomi para pekerja dan pedagang di karesidenan Surakarta khususnya. Kesenjangan sosial ini dipicu oleh kebijakan pemerintah Belanda yang membedakan antara pribumi, bangsawan dan beberapa masyarakat Tionghoa. Bagi anak-anak priayi memiliki kesempatan untuk meneruskan pendidikan dengan model Belanda yang bersifat sekuler dan terkesan diskriminatif. Sementara itu masyarakat Tionghoa memiliki kedudukan khusus dalam bidang ekonomi pada pemerintahan Belanda. Hubungan perdagangan antara negara Tiongkok dan masyarakat China di Hindia Belanda dianggap mampu membawa keuntungan besar bagi pemerintahan Hindia Belanda pada waktu itu. Akibat kemajuan di bidang perdagangan itu maka pemerintah Hindia Belanda mengambil alih sistem pembiayaan pendidikan China dengan cara mendirikan sekolah China-Belanda Hollandsche Chineesche Scholen (HCS). ${ }^{10}$

Kesenjangan sosial ini berdampak kepada kesenjangan ekonomi di tingkat para pekerja pribumi dan pekerja etnis China. Para pekerja China yang bekerja di perkebunan-perkebunan dan pabrik-pabrik milik orang Eropa dan China mendapatkan penghasilan rata-rata (dari awal penerapan politik etis hingga tahun 1925 an) 370 Gulden per keluarga atau setara \$148 per tahun.

${ }^{10}$ Nasihin, Sarekat Islam Mencari Ideologi, h. 31.

Walisongo, Volume 23, Nomor 1, Mei 2015 
Masyarakat pribumi yang hanya bekerja sebagai petani biasa dan tenaga kerja lepas (casual laborers) hanya mendapat 101-120 Gulden.11

Kondisi ini membuat Samanhudi, sebagai aktor santri pribumi, membuat sebuah gerakan sosial. Ia sanggup memobilisasi sumber daya yang ada dengan membingkai kemiskinan para kaum pribumi dengan semangat perjuangan Islam. Pada awal-awal abad ke 20, pemerintah Belanda memulai zaman baru dalam sistem politik etis kolonial di Indonesia. Dukungan untuk menerapkan sistem politik etis yang dimotori oleh Conrad Theodore van Deventer menjadikan kaum muda pribumi mendapat kesempatan untuk lebih aktif berorganisasi dan memiliki pendidikan formal. ${ }^{12}$

Merujuk pada teori struktur kesempatan politik (political opportunity) dalam teori teori gerakan sosial, politik etis yang diterapkan ini kemudian tidak disia-siakan oleh Samanhudi dalam melakukan pertentangan terhadap kebijakan pemerintah Belanda. Upaya yang dilakukannya adalah dengan mendirikan sebuah gerakan sosial pribumi dalam bidang ekonomi atau perdagangan, yang dikenal dengan Sarekat Dagang Islam. Gerakan SDI tak jarang menimbulkan sebuah gap yang serius antara masyarakat pribumi dan masyarakat Tionghoa. Beberapa bentrokan antara masyarakat pribumi dengan masyarakat Tionghoa ini membuat pemerintah Belanda menaruh curiga kepada Samanhudi sebagai aktor penggerak di balik peristiwa tersebut. ${ }^{13}$

Hal ini terus berlanjut hingga SDI bertransformasi menjadi Sarekat Islam (SI) yang juga memiliki semangat untuk menentang pemerintahan Belanda. Penentangan terhadap pemerintah Belanda terus dilancarkan oleh beberapa masyarakat pribumi yang bergabung bersama SI. Hingga pada tahun 1920, pergerakan SI terus mengalamai peningkatan signifikan dengan meningkatnya anggota SI. Aksi demonstrasi dan pemogokan para buruh kerja dilakukan di beberapa wilayah pabrik. Akhirnya Gurbernur Jendral Dirk Fork menerapkan kebijakan pemerintahan yang represif terhadap pergerakan masyarakat pribumi. ${ }^{14}$

\footnotetext{
${ }^{11}$ George McTurnan Kahin, Nationalism and Revolution in Indonesia, (New York: Cornell University Press, 1952), h.20.

${ }^{12}$ Nasihin, Sarekat Islam Mencari Ideologi, h. 27.

${ }^{13}$ Nasihin, Sarekat Islam Mencari Ideologi, h. 39.

${ }^{14}$ Agus Salim, "Hak Berserikat dan Berkoempoelan (pasal 33 RR)” dalam A.Zainoel Hasan, Aku Pemuda Kemarin di Hari Esok, Kumpulan Tulisan Pidato Tokoh Pergerakan Kebangsaan 1913-1938, (Jakarta: Jayasakti, 1981), h. 8.
} 
Melalui pergerakan Islam awal ini kita dapat membaca bahwa sejak masa pra kemerdekaan, Islam telah dijadikan sebagai ideologi strategis untuk menyampaikan wacana kemiskinan, kesenjangan sosial dan ketidak adilan pemerintah. Sebenarnya, bukan hanya Islam yang dijadikan sebagai ideologi perlawanan terhadap pemerintah Belanda. Ideologi sosialisme-komunisme pada tahun-tahun tersebut juga digunakan oleh beberapa orang yang lain untuk merebut negara dari pemerintahan Belanda. Bahkan di Solo dikenal sosok KH. Misbsch yang selalu melontarkan kalimat konvergensi dua ideologi, bahwa seorang Muslim harus pula seorang komunis jika ia memiliki semangat akan sistem politik yang membebaskan. ${ }^{15}$

Dapat dipahami apabila KH. Misbach melontarkan hal demikian, karena titik temu antara kedua ideologi ini adalah bahwa Islam memiliki semangat membela kaum mustad'afien, sementara sosialisme-komunisme -dalam istilah lain- membela kaum tertindas seperti kaum buruh dan petani. Satu titik temu ini seolah mempertemukan Islam dan komunisme dalam satu bingkai untuk bersama melakukan gerakan sosial.

\section{Orde Lama dan Orde Baru: Gerakan Abdullah Sungkar dan Abu Bakar Ba'asyir}

Gerakan Islamisme militan telah menjadi bagian dari sejarah sejak tahuntahun awal kemerdekaan Indonesia. Pada dasarnya, Gerakan Abdullah Sungkar dan Abu Bakar Ba'asyir hanyalah penerus dari gerakan Darul Islam (DI)/ Negara Islam Indonesia (NII) yang diproklamirkan oleh Kartosuwiryo pada 7 Agustus 1949 di Cisampak, Tasikmalaya.16 Abdullah Sungkar adalah seorang muballigh keturunan Hadhramiy yang lahir di Solo 1937 dan salah satu inisiator pendirian Pondok Pesantren Al-Mukmin Ngruki pada tahun 1972 selain Abu Bakar Ba'asyir. ${ }^{17}$ Abdullah Sungkar menempuh pendidikan dan memulai pengalaman organisasinya di Al-Irsyad ${ }^{18}$ Solo dan Gerakan Pemuda Islam

\footnotetext{
${ }^{15}$ Syamsul Bakri, Gerakan Komunisme Islam di Surakarta 1914-1942, (Yogyakarta: Universitas Islam Negeri Sunan Kalijaga, 2014).

16Lihat perjalanan sejarahnya pada Ahmad Yani Anshari, Untuk Negara Islam Indonesia, Perjuangan Darul Islam dan Al-Jama'ah Al-Islamiyah, (Yogyakarta: Siyasat Press, 2008).

${ }^{17}$ Selengkapnya mengenai pondok pesantren ini lihat tulisan Zuly Qadir, Ada Apa dengan Pesantren Ngruki? (Yogyakarta, Pondok Edukasi, 2003).

${ }^{18} \mathrm{Al}$-Irsyad sendiri pada awalnya adalah organisasi orang-orang Arab non-ḥabāib (bukan keturunan Nabi Muhammad). Organisasi ini termasuk pembawa ajaran Salafi ke Indonesia. Saat ini alIrsyad menjadi sebuah yayasan dan memiliki lembaga pendidikan setingkat SD, SMP dan SMA di Solo.
} 
Indonesia (GPII) dan kemudian menjadi simpatisan partai Masyumi (Majelis Syuro Muslimin Indonesia) di usianya yang masih relatif muda. Abdullah Sungkar sangat mengidolakan Natsir sebagai sosok politisi yang ia anggap memperjuangkan syariat Islam melalui partai Masyumi yang dipimpinnya. ${ }^{19}$ Nampaknya, dari Al-Irsyad inilah Sungkar telah mengenal ideologi Salafi, ditambah dengan aktifnya Sungkar di GPPI menjadikannya semangat berjuang untuk menegakkan syariat Islam sebagai suatu dasar negara.

Sungkar mulai akrab dengan Abu Bakar Ba'asyir, seorang muballigh yang juga keturunan Arab ketika keduanya membuat Radio Dakwah Islamiyyah Surakarta (RADIS) dan mendirikan pesantren Ngruki. ${ }^{20}$ Mulai aktif di dunia oposisi politik ketika keduanya masuk menjadi anggota DI pada tahun 1976. Sebelum masuknya Sungkar dan Ba'asyir ke DI, mereka berdua memiliki pemikiran untuk memobilisasi ulama Solo membangun sebuah jama'ah sebagai wadah perjuangan politik yaitu pendirian negara Islam. Sungkar dan Ba'asyir mengajar 12 ulama Solo non-partai termasuk Abdullah Marzuki (pendiri Pondok Pesantren As-Salam Solo) dan Abdullah Thuffail Saputra (Pendiri Majelis Tafsir al-Qur'an, MTA) untuk membentuk jama'ah. Sungkar dan Ba'asyir menggunakan atsar (perkataan sahabat) Umar yang menyatakan "lā islāma illā bi 'l-jamā'ah, wa lā jamā'ata illā bi 'l-imārah, wa lā imārata illā bi 'l-țā'ah" (tidak berislam seseorang kalau tidak masuk ke dalam jama'ah, tidak dianggap berjama'ah kecuali dengan kepemimpinan, dan tidak ada kepemimpinan kecuali dengan ketaatan. ${ }^{21}$ sebagai discoursive strategy (strategi wacana).

Tahun-tahun akhir 1970 hingga 1980-an adalah waktu yang sangat berarti bagi Sungkar dan Ba'asyir untuk mengonsolidasikan kekuatan di Solo raya, karena pada tahun itu Sungkar memegang kendali atas DI di wilayah Surakarta. Pada era Orde Baru tersebut Sungkar juga sangat aktif mengkampanyekan gerakan anti Pancasila yang dijadikan oleh Soeharto sebagai asas tunggal semua perkumpulan. Sungkar pernah menjadi kandidat imam DI sementara untuk menggantikan Adah Djailani yang sedang menjadi tahanan pemerintah. Ia dicalonkan bersama dua orang calon lainnya yaitu Abdul Fatah Wirananggapati, salah satu komandan Jawa Barat pertama, dan Ajengan Masduki yang diusulkan oleh majelis Syuro DI pada tahun 1987. Namun ia kalah dengan seniornya yaitu

\footnotetext{
${ }^{19}$ Solahuddin, NII Sampai JI, Salafy Jihadisme di Indonesia, (Jakarta: Komunitas Bambu, 2011), h.140.

20Solahuddin, NII Sampai JI, Salafy Jihadisme di Indonesia, h.140.

21Solahuddin, NII Sampai JI, Salafy Jihadisme di Indonesia, h.142.
} 
Ajengan Masduki. Begitu terpilih sebagai pejabat imam, Masduki menempatkan Abu Bakar Ba'asyir selaku menteri keadilan, dan Abdullah Sungkar bertanggung jawab atas urusan luar negeri, terutama dalam rangka mencari dukungan politik dan pendanaan dari luar.

Tujuan utama kabinet Masduki adalah membangun dukungan internasional serta memperkuat kemampuan militer DI. Sungkar memusatkan diri dalam upaya mencari dana dari Arab Saudi dan Rabitah, sementara Broto, selaku anggota staff utama Mia Ibrahim, mendapat tugas memperlancar pengiriman rekrut DI ke Afghanistan. Pada tahun 1988, untuk kepentingan tujuan tersebut, Masduki berangkat bersama delegasi DI menuju Pakistan dan Afghanistan. Termasuk di dalamnya Abdullah Sungkar, Abu Bakar Ba'asyir, serta dua orang lain. Dalam kunjungannya tersebut, Sungkar yang paling vokal ketika berdialog dengan para elit mujahid di Afghanistan, hal ini karena Masduki memang tidak dapat berbicara Bahasa Arab dengan lancar. Sungkar memanfaatkan kunjungan tersebut untuk memperkenalkan Masduki kepada Abdul Rasul Sayaf, pendiri kamp di Sada yang tengah melatih para rekrutan DI, selain Abdullah Azzam, ideolog utama dari Salafi jihadis, berikut komandan mujahidin senior lainnya. ${ }^{22}$

Abdullah Sungkar dan Abu Bakar Ba'asyir masih terus bersama hingga DI terpecah ke dalam dua kubu. Ajengan Masduki tetap di dalam DI, dan Abdullah Sungkar-Abu Bakar Ba'asyir mengorganisir diri menjadi Jama'ah Islamiyyah. Ada dua sinyalemen terkait penyebab perpecahan ini. Perkiraan pertama adalah karena Sungkar-Ba'asyir semakin tidak setuju dengan tauhid Masduki yang cenderung bersifat sufistik. ${ }^{23}$ Versi lain menyebutkan bahwa pecahnya DI ini karena perebutan jabatan posisi Amir NII yang sebelum tahun 1992 diduduki oleh Adah Djaelani Tirtapradja. ${ }^{24}$

Sungkar-Ba'asyir berhasil mendirikan Jama'ah Islamiyah pada 1 Januari 1993, ideologi yang ia gunakan adalah ideologi Salafi Jihadis. JI menganggap rezim Orde Baru sebagai musuh yang harus diperangi karena sangat menindas kepentingan umat Islam, yaitu dengan menjadikan Pancasila sebagai asas tunggal dalam kehidupan bernegara serta bersifat represif terhadap kekuatan-

\footnotetext{
${ }^{22}$ International Crisis Group (ICG), "Recycling Militants in Indonesia, Darul Islam and Australian Embassy Bombing”, Asia Report, 22 Februari 2005, h. 21.

${ }^{23}$ Natsir Abbas, Membongkar Jama'ah Islamiyah, (Jakarta: Grafindo, 2003).

${ }^{24}$ Ahmad Yani Anshari, Untuk Negara Islam ..., h. 92.
} 
kekuatan lain yang mengancam kekuasaannya. Akibat kebijakan pemerintah itu maka kaum Islamisme tidak dapat bebas berbicara mengkritik pemerintah. Orde Baru dianggap sebagai kāfir maḥally, yaitu mereka yang sebenarnya dapat dikatakan beragama Islam dari wilayah satu wilayah, namun mereka berkuasa bukan atas nama Islam dan menjadikan ideologi selain syariat Islam sebagai dasar negara dan cenderung diktator. Dalam pandangan kaum JI, käfir maḥally tersebut lebih berbahaya daripada käfir ajnaby, yaitu kaum kafir yang menduduki negara-negara Muslim seperti di Palestina. ${ }^{25}$

Dalam posisinya sebagai Amir Jama'ah Islamiyah, Sungkar juga gencar melakukan perekrutan anggota dari beberapa kota termasuk Solo, yang ia gerakkan dari Malaysia. Tidak sulit bagi Sungkar-Ba'asyir untuk kembali membangun organisasi, karena paling tidak mereka telah memiliki basis masa di Solo, ditambah dengan model usrah yaitu model organisasi kekeluargaan dengan mentor-mentor khusus pada setiap kelompok, yang diadopsi dari Ikhwanul Muslimin dalam mengorganisir jama'ah. ${ }^{26}$

Ketika nuansa politik di Indonesia berada dalam kekacauan akibat krisis berkepanjangan, yang berdampak pada lengsernya rezim Orde Baru, SungkarBa'asyir kembali ke Tanah Air setelah pelariannya selama kurang lebih 15 tahun dari Malaysia. Mereka mendapat sambutan baik yang luar biasa dari para jama'ahnya yang ada di Indonesia. Namun tidak lama setelah kepulangannya ke Tanah Air, Sungkar menghembuskan nafas terakhir karena sakit yang dideritanya pada 1999. Padahal beberapa jama'ah Sungkar sudah bersiap kembali untuk memperjuangkan ide politik Islamnya dengan mengumpulkan banyak jamaa'ah yang tersebar di sekitar Solo.27

Perjuangan politik pun dilanjutkan oleh Ba'asyir. Alam demokrasi nampaknya juga dinikmati oleh Ba'asyir dan para jama'ahnya. Pada tahun-tahun awal era reformasi, Ba'asyir kembali sering mengisi pengajian di beberapa masjid di Solo seperti Masjid al-Ikhlas dan Baitul Amin Cemani, Masjid Laweyan, dan Masjid Marwa Semanggi. ${ }^{28}$ Setelah kejadian Bom Bali 2002, Ba’asyir ditangkap

\footnotetext{
${ }^{25}$ Solahuddin, NII Sampai JI, Salafy Jihadisme di Indonesia, h.274.

26Mengenai usrah ini bisa dilihat pada karya Muhammad Shakirin Shaari dan Zulikha Jamaludin, "Towards an Islamic Lifelong Learning Information System: A Visionary Model of an Islamic Learning Community", makalah International Conference on Computing and Informatics (ICOCI), Bandung 2011, h. 88-91.

27Wawancara dengan Yusuf Parmadi, salah satu jama'ah setia Abdullah Sungkar dan Sekretaris Jendral Laskar Umat Islam Surakarta (LUIS), Solo, Februari 2015.

28Wawancara dengan Yusuf Parmadi.
} 
dengan tuduhan memiliki keterkaitan dan jaringan dengan Jama'ah Islamiyah yang ada di Mesir dan Afghanistan.

\section{Terbukanya Pintu Demokrasi: Gerakan Islam Radikal Lokal Era Reformasi}

Lengsernya Soeharto membawa implikasi yang luas dalam perpolitikan nasional. Laju gelombang demokratisasi sudah terlalu kuat untuk dibendung. Huntington mengatakan gelombang demokratisasi dapat diketahui dengan lahirnya kelompok-kelompok pada masa transisi dari rezim-rezim non-demokratis ke rezim yang lebih demokratis, yang terjadi dalam kurun waktu tertentu dan dengan jumlah sangat signifikan lebih banyak daripada kelompok pada masa transisi menuju arah sebaliknya (non-demokratis). ${ }^{29}$ Beberapa hal yang dikatakan Huntington ini dapat dianalisis dari beberapa hal, di antaranya terciptanya ruang kebebasan pers, aksi dan gerakan sosial yang semakin leluasa menunjukkan eksistensinya, sistem pemilihan yang semakin demokratis, hingga kebebasan berkumpul, berserikat dan membentuk organisasi yang telah dijamin undang-undang dengan ragam ideologi dan keyakinan (kecuali komunisme). Semua hal ini tiba-tiba hadir dalam jumlah yang banyak sebagai wahana baru bagi civil society.

Tidak disangka, demokratisasi dimanfaatkan bukan hanya dari kalangan nasionalis yang menerima Pancasila sebagai ideologi negara. Beberapa perkumpulan Islam yang secara geneologi mengakar pada kelompok Islamisme masa lalu (seperti DI/NII) juga berkembang di tengah euforia demokrasi yang terjadi di Indonesia. Beberapa kelompok ingin mensucikan dan menegakkan syariat Islam sebagai sebuah buku panduan dalam memberantas ketidakadilan, kesewenang-wenangan dan perilaku amoral lainnya seperti perjudian, mabukmabukan dan perzinahan.

Sebagai contoh di Jakarta, berdiri gerakan yang ingin menjadikan syariat Islam sebagai sebuah acuan dalam memberantas kemaksiatan yaitu Front Pembela Islam (FPI). Di Solo, muncul beberapa gerakan yang lebih percaya diri untuk membangun identitasnya sebagai sekelompok orang yang ingin memperjuangkan Islam politik. Terbentuklah beberapa gerakan laskar lokal Solo yang memiliki ideologi untuk memperjuangkan cita-cita tersebut seperti laskar

\footnotetext{
${ }^{29}$ Samuel P. Huntington, The Third Wave: Democratization in the Late Twentieth Century, (Oklahoma: University of Oklahoma Press, 1991) h. 13.
} 
Jundullah, yang merupakan sayap dari Forum Komunikasi Aktivis Masjid (FKAM, 1999), Hisbullah, (1999), Front Pemuda Islam Surakarta (FPIS, 1999) dan Laskar Umat Islam Surakarta (LUIS, 2000), hingga Tim Hisbah.

FKAM adalah salah satu organisasi masyarakat (ormas) Islam lokal Solo yang terbentuk di tengah hingar bingarnya krisis politik dan tuntutan reformasi pada tahun 1998. FKAM dibidani oleh beberapa aktivis Masjid al-Amin Sondakan Kecamatan Laweyan, Surakarta. Beberapa di antara pendiri tersebut adalah Muhammad Kalono, M. Sholeh Ibrahim, Yayan, Agus Priyanto dan Maman Abdurrahman. FKAM aktif melakukan advokasi dan kampanye terhadap isu-isu yang merugikan umat Islam seperti invasi militer Amerika atas Afghanistan dan Irak, pemberitaan terorisme, hingga mengkampanyekan pembebasan atas ketertindasan umat Islam selama Orde Baru dan turut ikut andil dalam menggulingkan penguasa otoriter tersebut. Layaknya ormas Islam lainnya, FKAM memiliki satuan tugas keamanan atau sayap organisasi yang sifatnya paramiliter, sayap organisasi FKAM mereka namakan dengan Laskar Jundullah.

Selain FKAM, laskar yang kerap melakukan aksi-aksi lain adalah Laskar Hizbullah. Laskar ini sebenarnya kurang sesuai jika dikatakan sebagai gerakan Islamisme lokal, karena secara organisatoris Laskar Hizbullah berada di bawah payung Partai Bulan Bintang (PBB) yang berdiri pada tahun 1998. Namun, Laskar Hizbullah di wilayah Solo Raya sangat aktif melakukan aksi anti kemaksiatan dan menyuarakan penerapan syariat Islam di bawah komando Yani Rahmanto. Inilah yang membedakan Laskar Hizbullah dengan laskar lainnya yang berada di luar Kota Solo. Sebagaimana partisan partai politik lainnya, Laskar Hizbullah juga aktif berkampanye untuk kemenangan PBB dalam Pemilu 1999. Laskar Hizbullah memiliki anggota yang berasal dari kaum muda Solo. ${ }^{30}$

Gerakan Islamisme lain adalah Front Pemuda Islam Surakarta (FPIS). FPIS terbentuk pada tahun 1999 oleh beberapa orang yang pada dasarnya pernah menjadi jama'ah pengajian Gumuk (Jama'ah Gumuk) ${ }^{31}$ seperti Warsito Adnan

\footnotetext{
30Wawancara Atif, Rahman dan Amin, simpatisan gerakan-gerakan Islam di Solo, Semanggi, Februari 2015.

31Jama'ah Gumuk adalah kelompok pengajian yang didirikan oleh H. Mudzakkir pada tahun 1976 di sebuah masjid di daerah Gumuk, Mangkubumi, Solo. Pada tahun 1980-an, masjid Gumuk dicurigai oleh beberapa kelompok di Solo sebagai tempat pengajian eksklusif kalangan Syi'ah. Alasan atas kecurigaan ini adalah bahwa Mudzakir pernah menimba ilmu di Yayasan Pendidikan Islam (YAPI) Bangil, salah satu yayasan di Indonesia yang berafiliasi kepada Syi'ah Itsna 'Asyariah di Iran. Selain itu,
} 
dengan pemicu yang sama seperti Laskar Jihad: yaitu permasalahan konflik Ambon, meskipun memang mereka tidak secara langsung terjun untuk melibatkan diri (secara institusional). FPIS pada tahun-tahun selanjutnya menjadi sebuah gerakan anti maksiat dan ikut menanggapi isu-isu politik nasional, bahkan isu-isu internasional yang dianggap cenderung menyudutkan umat Islam. Salah satu contohnya adalah kebijakan Amerika Serikat yang gencar untuk melawan terorisme. Selain itu setelah jatuhnya era Orde Baru, FPIS seakan diakuisisi oleh Jama'ah Gumuk karena anggotanya yang dominan dari jama'ah tersebut. ${ }^{32}$ Namun saat ini, FPIS sedikit berseberangan dengan beberapa gerakan Islamisme lokal lainnya seperti LUIS dan Tim Hisbah. Hal ini karena para anggotanya yang terkena imbas perjalanan Mudzakkir yang pernah mempelajari Ilmu Islam di beberapa tempat yang disinyalir sebagai pusat pergerakan Syi'ah seperti di Iran dan di Yayasan Pendidikan Islam (YAPI) Bangil.

Beberapa kelompok lokal ini menemukan momentumnya untuk mengkonsolidasikan kekuatan ketika peristiwa pertikaian Ambon Berdarah. Pada pertengahan tahun 1999, umat Islam di Kota Solo dihebohkan dengan rumor yang beredar bahwa pihak-pihak Kristen akan berusaha menyebar konflik ke luar Maluku. Rumor ini didasari dari banyaknya selebaran gelap yang beredar bahwa Solo adalah kota tujuan untuk menyulut konflik tersebut dengan alasan bahwa banyaknya pondok yang berdiri sebagai pondok anti Kristen dan ingin menghancurkan Kristen, karenanya pihak Kristen telah melakukan pembekalan termasuk pelatihan militer untuk persiapan konflik Solo berdarah. Beberapa permasalahan ini telah dibicarakan dalam sebuah rapat tertutup di Sekolah Menengah Kejuruan Kristen (SMKK) Simo Boyolali pada akhir Maret 1999.33

Informasi gelap tersebut menjadi ramai ketika terjadi insiden penyerangan Pondok Pesantren Darus Syahadah, Simo Boyolali pada malam hari 8 April 1999. Sebuah truk yang membawa sekelompok massa datang ke pesantren tersebut dan memutus kabel aliran listrik pesantren, lalu mereka masuk ke dalam komplek dan berniat merusak pesantren. Namun kejadian tersebut dilawan oleh para santri yang ada, akhirnya massa yang tidak dikenal tersebut

Mudzakir juga pernah belajar Islam di Iran. Tapi semua itu dibantah oleh jama'ahnya karena mereka juga belajar kitab karangan beberapa ulama Sunni seperti Ahmad Mustafa al-Maraghi dan Ibnu Katsir.

${ }^{32}$ Muhammad Wildan, "Mapping Radical Islamism in Solo: a Study of the Proliferation of Radical Islamism in a Town in Central Java", dalam Martin van Bruinessen (ed.), Contemporary Developments In Indonesian Islam..., h. 55.

${ }^{33}$ Majalah Media Dakwah, edisi Mei 1999, h.10. 
kembali menuju truk dan meninggalkan pesantren ${ }^{34}$ Insiden yang terjadi di Pesantren Darus Syahadah ini kemudian dikaitkan dengan informasi gelap yang beredar akan adanya kerusuhan serupa Ambon berdarah di Kota Solo. Saat itu beberapa komponen umat Islam bersatu untuk menggalang solidaritas dengan mengadakan apel siaga. Agenda mengenai perkumpulan dan apel siaga ternyata disambut baik oleh umat Islam. Pada tanggal 16 April 1999, ribuan organisasi masyararakat (ormas) Islam berkumpul di stadion Manahan Solo. Namun saat itu, LUIS belum terbentuk dan mobilisator massa dipegang oleh organisasi JI Solo. ${ }^{35}$

Satu tahun setelah awal tersulutnya konflik di Ambon pada Januari 1999 ternyata belum membawa kabar gembira akan perdamaian di tanah Manise tersebut. Alih-alih perdamaian, konflik atas nama agama kembali meledak di daerah lain di Indonesia, tepatnya di Poso Sulawesi Tengah pada April 2000. Kejadian tersebut direspon oleh beberapa elemen umat Islam di Solo secara konfrontatif. Beberapa orang yang mewakili organisasi Islam lokal di Solo kemudian melakukan pertemuan di Masjid Baitussalam Tipes, Solo.

Dalam pertemuan itu disepakati untuk membentuk organisasi tansikh atau semacam aliansi beberapa organisasi Islam yang siap menyambut isu konflik tersebut dengan melakukan aksi solidaritas Muslim di Kota Solo. Maka dibentuklah Laskar Umat Islam Surakarta (LUIS) dengan sepuluh orang inisiator utama pendirian organisasi: Edi Lukito, Salman al-Farisi, Hendro Sudarsono (Laskar Mujahidin), Jayendra Dewa, Yusuf Suparna, Muhammad Kalono (FKAM/Laskar Jundullah), Yani Rahmanto (Hizbullah), Khairul (FPIS), Heru Prayetno (Satuan Tugas Majelis Tafsir al-Qur'an, Satgas MTA) dan Sriyadi (Komando Kesiapsiagaan Angkatan Muda Muhammadiyah, KOKAM). Pertemuan tersebut juga mengagendakan mengenai konferensi umat Islam dan apel siaga di Stadion Manahan Solo. Agenda mengenai perkumpulan dan apel siaga ternyata disambut baik oleh umat Islam. Pada tanggal 16 Desember 2000, beberapa ormas Islam kembali memadati stadion Manahan Solo untuk melakukan aksi solidaritas dan apel siaga. ${ }^{36}$

Setelah LUIS terbentuk, dan diketuai oleh Edi Lukito, para anggota didominasi oleh kalangan Islamisme Solo. Para laskar LUIS aktif melakukan

\footnotetext{
${ }^{34}$ Majalah Media Dakwah, edisi Mei 1999, h. 13.

35Wawancara dengan Yusuf Parmadi, Solo, 4 Maret 2015.

36Wawancara dengan Yusuf Parmadi, Solo, 4 Maret 2015.
} 
pengawalan terhadap kegiatan-kegiatan di sekitar Solo, LUIS lebih banyak bergerak dalam advokasi non-litigasi, misalnya isu penegakan syariat Islam, isu stigmatisasi terorisme, isu Anti Amerika, isu penistaan agama, pemberantasan tempat-tempat maksiat, pemberdayaan umat Islam, isu pembubaran Ahmadiyah, hingga RUU Pornografi. LUIS melancarkan aksinya bukan hanya kepada masyarakat, melainkan ikut memprotes kebijakan instansi pemerintahan, misalnya meminta mediasi dengan Dewan Perwakilan Daerah (DPRD) Kota Solo untuk menyuarakan suara mereka atas pembubaran Detasemen Khusus (Densus) 88 Anti Teror Polri. Lembaga-lembaga pendidikan pun menjadi tempat tujuan aksi LUIS misalnya, kampanye anti valentine day di sekolah-sekolah.

Pada bulan Oktober 2014, para anggota LUIS berkumpul dan berorasi di area kampus Institut Agama Islam Negeri (IAIN) Surakarta untuk menyuarakan penistaan, penodaan dan kesesatan kaum Syi'ah terhadap agama Islam. Orasi itu merupakan reaksi atas kerja sama yang dijalin oleh IAIN Surakarta dengan Kedutaan Besar Iran di Indonesia untuk mendirikan Iranian Corner. Proses kerjasama diawali dengan kunjungan Duta Besar (Dubes) Iran untuk Indonesia yang diwakili oleh Hojjatullah Ibrahimian dan mempromosikan Iran sebagai sebuah Negara dengan banyak warisan peradaban Persia dan sebagai Negara Islam modern saat ini. ${ }^{37}$ Kabar pendirian Iranian Corner tersebut terdengar oleh LUIS, mereka menolak karena menjaga Islam sebagai sebuah agama yang murni dan tidak ingin Syi'ah yang menodai agama Islam berkembang di Indonesia, hal ini semakin tidak diterima karena Syi'ah justru hadir melalui Perguruan Tinggi Islam. ${ }^{38}$

Nama gerakan Islam radikal yang lahir paling muda di alam reformasi adalah Tim Hisbah. Kelompok ini didirikan oleh Sigit Qardhawi, seorang pemuda asli Solo yang kerap menjadi koordinator gerakan aksi gabungan beberapa kelompok Islam radikal di Solo. Sigit mencoba untuk mengawali karir politik dengan bergabung menjadi anggota Partai Bulan Bintang (PBB) bersama beberapa kawan lainnya di Kartopuran Solo. Sigit sempat beberapa kali aktif melakukan pertemuan membahas kesuksesan partai pada pemilu 1999.39 Namun demikian, setelah melewati pemilu, Sigit lebih memfokuskan diri untuk bergabung dengan Laskar Hizbullah, gerakan sayap dari PBB. Sigit

\footnotetext{
37Wawancara dengan Syamsul Bakri, Wakil Dekan Fakultas Ushuluddin dan Dakwah Institut Agama Islam Negeri (IAIN) Surakarta, Desember 2014.

38Wawancara dengan Edi Lukito, Panglima Laskar Umat Islam Surakarta (LUIS), Solo, 2 Maret 2015.

${ }^{39}$ Wawancara dengan Mohamad Arif, Purwosari, Solo, Februari 2015.
} 
memilih untuk memfokuskan diri di sana karena memungkinkannya dapat terlibat langsung dalam kegiatan amar márūf nahī munkar. Selain itu juga karena menurut pandangannya partai politik kotor karena hanya mementingkan para pemegang modal yang menjadi petinggi partai.

Sigit kemudian banyak melakukan kegiatan amar ma'rūf nahī munkar bersama Laskar Hizbullah. Dalam kegiatan tersebut Sigit merupakan tokoh yang paling vokal dalam menyuarakan perlawanan terhadap perilaku maksiat seperti judi dan mabuk-mabukan. Dalam beberapa kegiatan aksi gabungan di wilayah Solo Sigit sering menjadi koordinator. Aksi sweeping yang seringkali dilakukan oleh kelompok ini karena menurutnya aparat keamanan kurang bertindak tegas dalam penindakan kriminal dan pencegahan minuman keras di Solo.

Dari pergerakan inilah Sigit banyak mendapatkan simpati dari beberapa ikhwan ${ }^{40}$ lainnya. Aksi sigit baru mendapatkan perhatian serius dari aparat keamanan pada tahun 2005, ketika Sigit memimpin aksi gabungan dari beberapa gerakan Islamisme di Solo lainnya yang menggelar sweeping di Kafe Pring Kuning dan Restoran Waru Doyong, Grogol Sukoharjo. Dua tempat ini sudah diintai lama oleh Sigit dan kelompoknya karena sering menjual minuman keras secara terbuka dan tanpa ada rasa takut sedikit pun. Aksi ini sempat menimbulkan kericuhan di sekitar kawasan kafe hingga aparat keamanan datang dan menangkap koordinator aksi gerakan yaitu Sigit, Khalid dan Awud. Karena aksi ini Sigit dan dua orang lainnya ditahan di kepolisian selama tiga bulan.

Setelah bebas dari penjara, Sigit menjadi sosok yang banyak disegani beberapa ikhwan di Solo. Karena kasus inilah Sigit memutuskan untuk keluar dari PBB yang dianggapnya hanya memperalat beberapa ikhwan demi kepentingan negara demokrasi yang jelas (menurutnya) tidak menjadikan syariat Islam sebagai sumber hukum. Pada tahun 2006 Sigit membentuk jama'ah sendiri dan sering melakukan kegiatan di Masjid Arafah. ${ }^{41}$ Semenjak itu, dengan modal keilmuannya, sigit memberanikan diri untuk menjadi da'i dengan menyampaikan tausiah di beberapa masjid, terutama Masjid Arafah. Sigit kerap mengajak

\footnotetext{
40Ikhwān dalam tata bahasa Arab adalah bentuk jamak dari akhun, yang secara harfiah dalam bahasa Arab berarti saudara. Sebutan yang biasa digunakan oleh anggota gerakan Islamisme untuk menunjuk kepada beberapa anggota lainnya yang sepaham dan seideologi.

${ }^{41}$ Beberapa Informasi tentang Sigit Qardhawi penulis dapatkan dari hasil wawancara penulis terhadap berbagai informan: Agus, Atif, Amin hingga keluarga (adik dan ibu kandung) Sigit. Solo, Maret 2015.
} 
beberapa rekannya untuk ikut andil dalam perbaikan akhlak dan moral masyarakat Solo yang dianggap jauh dari moral yang diidealkan oleh Islam. Sigit melakukan kegiatan anti kemaksiatan setiap malam minggu, mengontrol wilayah Solo dan sekitarnya agar terhindar dari perbuatan yang diklaim oleh Sigit dan para anggota gerakan lainnya melanggar aturan Islam. Kegiatan ini terus dilakukan Sigit hingga Ia meninggal dunia dalam sebuah operasi Densus 88 Mabes Polri pada Mei 2011 lalu dengan tuduhan terorisme terkait bom bunuh diri di Mapolres Cirebon.

Jejaring yang telah terbentuk selama Sigit aktif di dunia gerakan laskar membuatnya tidak sulit untuk mengumpulkan massa. Massa yang berasal dari jama'ah pengajian di beberapa masjid merupakan sumber daya informal yang dapat digerakkan ketika melakukan sebuah aksi, dan ini diteruskan oleh ketua Laskar Hisbah selanjutnya yaitu Agus Junaedi. Ketika timbul sebuah pertanyaan mengapa mereka mampu dan mau bergerak, Sidney Tarrow menjelaskan dengan cukup rasional bahwa sebuah gerakan militan memiliki beberapa hal dasar yang harus dipupuk (basic properties of movements). Di antaranya adalah tantangan kolektif (collective challenge) yang membuat mereka harus melakukan sebuah penyelaan pendapat (interrupting), menghalangi kegiatan (obstructing) dan perlawanan (opposing) secara bersama-sama, ditujukan untuk aktivitas kelompok lain yang tidak memiliki ideologi seperti mereka, atau sikap yang bertentangan dengan Islam.

Hal dasar lainnya adalah tujuan bersama (common purpose), hal ini mereka gunakan untuk meraih kepentingan kelompok. Karena tujuan bersama inilah yang menjadi alasan mereka rela mengambil resiko untuk bertindak secara kolektif dengan mengatas namakan solidaritas kelompok, yaitu rasa senasib dan seperjuangan di dalam sebuah komunitas. Tidak cukup sampai di situ, sebuah pergerakan yang militan memiliki pertahanan aksi kolektif. Mereka harus mampu mempertahankan kelompok dari berbagai tantangan dengan memanfaatkan kesempatan apa saja yang hadir di sekitar mereka.42

Penggunaan jejaring sosial dan sumber-sumber daya informal untuk mobilisasi sangat lazim ditemukan dalam masyaraka-masyarakat atau enklave yang kurang terbuka. Karena hanya dengan seperti itu sebuah gerakan dapat mempertahankan aktivismenya, dengan sumber daya yang berakar pada

${ }^{42}$ Sidney Tarrow, Power in Movement..., h.3-5. 
hubungan-hubungan sosial sehari-hari sehingga tidak terlacak oleh lawan politik termasuk rezim yang represif. 43

\section{Islam Radikal: Gerakan Sosial dan Peneguhan Identitas}

Melihat berbagai reaksi Islam pada masa pra-kemerdekaan, awal kemerdekaan Orde Baru, hingga era Reformasi menghadirkan sebuah pertanyaan. mengapa masyarakat Muslim Solo selalu muncul di permukaan dalam bentuk radikal untuk melakukan gerakan perlawanan di setiap zaman? Wildan mencoba menjawabnya dengan menggunakan trikotomi masyarakat Jawa Clifford Geertz Jawabannya bukan karena banyaknya masyarakat Muslim yang menguasai ruang publik, namun hal ini justru dikarenakan banyaknya masyarakat abangan yang berhasil diprovokasi oleh pemangku kepentingan gerakan Islam radikal. Mereka tetap bukan aliran mainstream di Solo, namun mereka selalu muncul di permukaan. ${ }^{44}$

Disparitas ekonomi, sosial dan politik telah membuat masyarakat terbuai akan janji-janji Islam yang membebaskan. Ketika zaman penjajahan mereka melemparkan isu-isu perlawanan atas ketertindasan masyarakat pribumi dengan satu kata "jihad". Ketika zaman berubah menjadi negara merdeka, dalam pemerintahan represif para aktor gerakan Islamisme membuat sebuah gerakan anti slogan-slogan pemerintah seperti anti Pancasila dan menawarkan Islam sebagai format negara tandingan. Pada era reformasi, di mana nuansa politik dituntut harus lebih demokratis, gerakan Islamisme lebih leluasa untuk bersuara, berserikat dan berkumpul tanpa adanya tuduhan kelompok subversif.

Dengan demikian gerakan berhasil membingkai kemiskinan, ketidakadilan, kebobrokan moral hingga adanya konspirasi besar dari negara adidaya untuk menghancurkan negara-negara Muslim karena dianggap sebagai lawan politik, dan menawarkan Islam sebagai sebuah solusi untuk segala permasalahan. Untuk itu, fokus para anggota gerakan bukan lagi soal Jihad dalam konteks peperangan, namun lebih ke arah amar ma'rūfnahī munkar, paling tidak dalam lingkup lokal.

Masyarakat abangan saja tidak cukup untuk dijadikan faktor tunggal akan aksi-aksi radikal, karena banyak di beberapa wilayah yang terdiri dari masyarakat abangan tidak turut menyumbang aksi-aksi Islam radikal. Sebagai-

\footnotetext{
${ }^{43}$ Quintan Wiktorowicz (ed.), Islamic Activism..., h.12-13.

${ }^{44}$ Lihat Penelitian Muhammad Wildan, "Mapping Radical Islamism in Solo...", dalam Martin van Bruinessen (ed.), Contemporary Developments In Indonesian Islam..., h.190-222.
} 
mana keberhasilan Ja'far Umar Thalib dalam membentuk Laskar Jihad pada tahun 1999 yang keberhasilannya dipengaruhi juga keberhasilan ekspansi kaum Salafi di Indonesia dalam berbagai bidang, di antaranya lembaga sosial dan pendidikan, ${ }^{45}$ Menjamurnya gerakan Islamisme pun tidak lepas dari peran serta ideologi Salafi jihadis di Solo yang dibawa oleh aktor terdahulu, Abdullah Sungkar dan Abu Bakar Ba'asyir. Para aktor gerakan Salafi jihadis ini berhasil menancapkan ruh perlawanan terhadap rezim berkuasa dengan melakukan ekspansi ideologi di Indonesia, khususnya di Solo. Mengapa mereka dapat dipengaruhi oleh ideologi jihadis tersebut? Pertanyaan ini sebenarnya diperlukan uraian yang panjang guna menghindari simplifikasi jawaban yang mengakibatkan keakuratan analisis menjadi kecil.

Para sosiolog terdahulu mengedepankan sebuah teori yang dinamakan deprivasi relatif (relative deprivation) dalam menganalisa sebuah pertentangan politik. Teori ini memiliki empat alur untuk menganalisis sebuah fenomena sosial. Alur ini terdiri dari dua variabel (diibaratkan A dan B) dan satu objek (X). Pertama, variabel A sadar bahwa ia tidak memiliki X. Kemudian A mengetahui bahwa terdapat variabel lain (B) yang memiliki X. Karena A menyadari bahwa segala kekurangannya disebabkan karena ia tidak memiliki X, karenanya $\mathrm{A}$ ingin memiliki X. Setelah itu A memiliki keyakinan bahwa X harus dimiliki untuk menutupi sebuah kekurangan tersebut, maka merebut $X$ adalah sesuatu yang relistis menurut $\mathrm{A}^{46}$

Dalam kasus radikalisme agama, A diibaratkan pemangku kepentingan gerakan Islam radikal. X adalah sebuah objek yang diperebutkan, yaitu politik dan kekuasaan. Keadaan sosial masyarakat yang semakin terjepit oleh disparitas modal kapital, membuat kalangan menengah ke bawah membentuk sebuah pergerakan perlawanan untuk merebut kekuasaan. Dengan bumbubumbu agama, dan bingkai-bingkai kemiskinan, mereka percaya bahwa kekuasaan harus dimiliki oleh kalangan mereka bagaimanapun caranya untuk merebut. Akhirnya tindakan kekerasan pun dilakukan sebagai realisasi awal untuk mewujudkan usaha kepemilikan kekuasaan tersebut.

Namun, teori deprivasi relatif saat ini sudah mulai ditinggalkan banyak sosiolog karena dianggap kurang relevan dalam membaca beberapa kasus,

\footnotetext{
${ }^{45}$ Baca: Noorhaidi Hasan, Laskar Jihad, Islam, Militansi dan Pencarian Identitas di Indonesia Pasca Orde Baru, (Jakarta: KITLV, 2008).

46Walter G. Runciman, Relative Deprivation and Social Justice: a Study of Attitudes to Social Inequality in Twentieth Century England, (Oakland: California University Press, 1966), h. 71.
} 
seperti Islam radikal. Faktanya, banyak masyarakat kelas menengah yang tidak ikut andil dalam aksi-aksi radikal tersebut, atau sebaliknya, tidak jarang masyarakat yang berkecukupan yang ikut dalam aksi tersebut. Perhatian para sosiolog kemudian beralih kepada teori identitas sebagai pelengkap dari teori deprivasi relatif, dan sekarang dikenal dengan politik identitas. Calhoun menyatakan bahwa identitas butuh sebuah pengakuan dari orang di luar diri seseorang. Hal ini yang menjadi penting dalam pembahasan politik identitas, bahwa aksi darigerakan Islam radikal sebenarnya ingin menunjukkan bahwa mereka butuh pengakuan dari sebuah masyarakat luas berikut dengan ideologi mereka yakini sebagai kebenaran. Castells menyebut identitas yang diperjuangkan tersebut bukan tanpa sebab, identitas dibangun karena melewati setidaknya tiga perjalanan identitas. ${ }^{47}$ Pertama, identitas legitimasi (legitimizing identity), yaitu identitas yang diperkenalkan oleh sebuah institusi yang mendominasi suatu masyarakat. Misalnya pada zaman orde Baru periode awal, di mana Islam dengan pesantrennya menjadi identitas yang terlegitimasi tidak membawa perkembangan untuk kemajuan pembangunan. Dalam konteks seperti ini Islam hanya dipandang sebagai biang teroris yang konsep politiknya tidak menghargai pluralisme dan tidak dapat membawa kesejahteraan dan kesetaraan.

Kedua, identitas resisten (resistance identity), yaitu proses pembentukan identitas dalam kondisi tertekan oleh pihak lain sehingga membangun resistansi dengan tujuan keberlangsungan hidup kelompok dan golongan. Identitas ini bisa digunakan untuk menggambarkan aksi Islam radikal yang hidup pada enclave tertentu yang dikelilingi oleh jama'ah mereka sendiri. Hal ini dilakukan sebagai bentuk ekspresi ketidakpuasan, kefrustasian dan kekecewaan, dan ini utamanya dialami oleh kaum muda. Dalam tembok enclave kecil inilah pengikut gerakan radikal mengonsolidasikan identitas sebagai perlawanan terhadap kehidupan luar yang menentang mereka. Mereka beraksi di bawah kontrol ideologi dan gerakan sosial. Ketika mereka beraksi, masyarakat luas mengetahui -dengan bantuan media- bahwa aksi mereka di luar kontrol negara dan dinilai sebagai aksi radikal dan cenderung mendapatkan stigma negatif.

Ketiga, identitas proyek (project identity), yaitu suatu identitas lama yang dibentuk menjadi suatu identitas baru sehingga dapat menentukan posisiposisi baru dalam masyarakat sekaligus mengubah pandangan masyarakat terhadap identitas lama. ${ }^{48}$ Identitas proyek ini dapat kita sentuhkan dengan

${ }^{47}$ Calhoun dalam Manuel Castells, The Power of Identity, (Oxford: Blackwell Publishing Ltd, 2010), h. 6.

${ }^{48}$ Manuel Castells, The Power of Identity, h. 8. 
kasus gerakan Islam di Solo, misalnya, para anggota Islam radikal melakukan aksi sweeping atas nama masyarakat, bahwa masyarakat resah, masyarakat terganggu, ataupun masyarakat tidak senang dengan tindakan yang mereka anggap sebagai perbuatan amoral. ${ }^{49}$

Identitas ini membawa pengaruh besar terhadap individu-individu yang pernah dikecewakan oleh kondisi sosial-politik nasional. Ketika sekelompok orang merasa dalam posisi yang dirugikan dan dalam perasaan tertindas secara identitas, maka ia sangat mudah untuk digerakkan menuntut sesuatu yang tidak dimilikinya. Dalam hal ini doktrin politik Islam hadir sebagai penggerak dari kegelisahan masyarakat. Doktrin-doktrin Islam seperti ini memiliki ciri pemahaman totalistik dan formalistik, yang bersikap latterlijk dalam memahami teks-teks agama, sehingga harus merujuk perilaku Muhammad dan para sahabat secara literal dan cenderung menolak perubahan sosial. Pada saatnya mereka menjadikan doktrin ini sebagai obat frustasi terhadap perubahan dunia yang begitu cepat. Doktrin agama -dalam hal ini Islam- dapat dimanfaatkan untuk merubah seseorang from zero to hero, dari sebelumnya merupakan sosok yang nothing menjadi pribadi yang everything.

\section{E. Kesimpulan}

Melalui analisis sosiologi dengan teori gerakan sosial dan identitas yang telah di bahas sebelumnya, kita dapat mengetahui bahwa radikalisme dapat dianalisis melaui perspektif yang berbeda, selain perspektif teologi. Proses deradikalisasi bukan perkara mudah. Radikalisme bukan hanya soal kesalahan ideologi agama yang mereka terima, radikalisme menggambarkan fenomena sosial masyarakat yang begitu kompleks yang meliputi persoalan keagamaan, kesenjangan sosial, politik, pendidikan, penegakan hukum hingga masalah perjuangan identitas. Karenanya, penanganan tidak cukup hanya dengan me-reinterpretasi ayat-ayat suci yang dapat menggiring seseorang kepada radikalisme, menjadi interpretasi atau penafsiran kontekstual, humanis dan inklusif.

Usaha semacam itu paling tidak hanya menggema dan berakhir pada ruang-ruang seminar dan kelas-kelas perkuliahan. Masyarakat akar rumput (grassroot) belum terlalu familiar dengan bahasa-bahasa interpretasi semacam itu, sehingga mereka mengambil sikap "acuh tak acuh" akan usaha para akademisi. Proses deradikalisasi membutuhkan kerja keras dari semua pihak

${ }^{49}$ Diutarakan oleh Agus Junaedi, Ketua Laskar Hisbah Solo, Semanggi Solo, Februari 2015.

Walisongo, Volume 23, Nomor 1, Mei 2015 
mulai dari aparat keamanan dengan penegakan hukumnya, para hakim dengan keadilannya, akademisi dengan keilmuannya, pendidik, pembuat kebijakan (policy maker), ekonom, elit politik hingga non-government organization (NGO) atau lembaga-lembaga yang dibangun dengan semangat demokrasi lainnya.

Disadari atau tidak, penanganan radikalisme selama ini masih mengacu pada "garangnya" aparat keamanan dan kekuatan senjata. Cara semacam ini juga ditempuh oleh negara super power Amerika Serikat ketika pemerintahan George W Bush. Amerika banyak melakukan tindakan pre-emptive action, yaitu tindakan yang mengebiri aksi-aksi yang dianggap bertentangan dengan cenderung menggunakan kekuatan perang. ${ }^{50}$ Akibatnya, pelaku radikalisme banyak yang ditangkap dan dilumpuhkan, namun gerakan dan identitasnya masih terbangun di masyarakat akar rumput dibeberapa daerah, salah satunya adalah Solo.

Dialog-dialog yang dilakukan pun masih sebatas kalangan akademisi teologi (baik Islam ataupun Kristen), hal ini memang karena fenomena radikalisme dianggap sebagai fenomena keagamaan belaka, tanpa ada kaitannya dengan gejala sosial, ekonomi dan politik. Dialog-dialog belum meluas pada taraf interdisipliner dalam membahas radikalisme yang melibatkan kajian ekonomi, kajian sosiologi, antropologi, sains dan teknologi, pendidikan, budaya, manajemen, ilmu pemerintahan, ilmu politik dan lain-lain. Dengan penelitian ini diharapkan akan membentuk kesadaran baru dan pembacaan baru dalam penanganan radikalisme dari multi-prespektif. Diharapkan juga akan sanggup membaca gejala radikalisme tidak hanya dari sisi interpretasi agama, tetapi juga dari sisi ilmu lainnya seperti ilmu sosial, khususnya dari teori-teori gerakan sosial dan identitas.[w]

50Zuly Qadir, Radikalisme Agama di Indonesia, (Yogyakarta: Pustaka Pelajar, 2014), h.136. 


\section{BIBLIOGRAFI}

Abbas, Natsir, Membongkar Jama'ah Islamiyah, Jakarta: Grafindo, 2003.

Bakri, Syamsul, Gerakan Komunisme Islam di Surakarta 1914-1942, Yogyakarta: Universitas Islam Negeri (UIN) Sunan Kalijaga, 2014.

Castells, Manuel, The Power of Identity, Oxford: Blackwell Publishing Ltd, 2010.

G. Runciman, Walter, Relative deprivation and Social Justice: a Study of Attitudes to Social Inequality in Twentieth Century England, Oakland: California University Press, 1966.

Hasan, Noorhaidi, Laskar Jihad, Islam, Militansi dan Pencarian Identitas di Indonesia Pasca Orde Baru, Jakarta: KITLV, 2008.

Khalil, Ahmad, Islam Jawa, Sufisme dalam Etika dan Tradisi Jawa, Malang: UIN Malang Press, 2008.

Kahin, George McTurnan, Nationalism and Revolution in Indonesia, New York: Cornell University Press, 1952.

Philips Huntington, Samuel, The Third Wave: Democratization in the Late Twentieth Century, Oklahoma: University of Oklahoma Press, 1991.

Qadir, Zuly, Ada Apa dengan Pesantren Ngruki?Yogyakarta: Pondok Edukasi, 2003.

Qadir, Zuly, Radikalisme Agama di Indonesia, Yogyakarta: Pustaka Pelajar, 2014.

Salim, Agus, Hak Berserikat dan berkoempoelan (pasal 33RR)" dalam A.Zainoel Hasan, Aku Pemuda Kemarin di Hari Esok, Kumpulan Tulisan, Pidato Tokoh Pergerakan Kebangsaan 1913-1938, Jakarta: Jayasakti, 1981.

Simuh, Islam dan Pergumulan Budaya Jawa. Jakarta: Teraju, 2003.

Solahuddin, NII Sampai JI, Salafy Jihadisme di Indonesia, Jakarta: Komunitas Bambu, 2011.

Tarrow, Sidney, Power in Movement; Social Movements, Collective Action and Politics, Cambridge: Cambridge University Press, 1995.

Van Bruinessen, Martin (ed.), Contemporary Developments In Indonesian Islam, Explaining The Conservative Turn, Singapore: ISEAS Publishing, 2013.

Wiktorowicz, Quintan (ed), Islamic Activism, a Social Movement Theory Approach, Indiana: Indiana University Press, 2004.

Walisongo, Volume 23, Nomor 1, Mei 2015 
Yani Anshari, Ahmad, Untuk Negara Islam Indonesia, Perjuangan Darul Islam dan Al-Jama'ah Al-Islamiyah, Yogyakarta: Siyasat Press, 2008.

\section{Majalah, Makalah dan Laporan Penelitian:}

International Crisis Group (ICG), "Recycling Militants in Indonesia, Darul Islam and Australian Embassy Bombing”, Asia Report, 22 Februari 2005.

Majalah Media Dakwah, edisi Mei 1999.

Majalah Tempo, edisi 7 Agustus 2005.

Muhammad Shakirin Shaari dan Zulikha Jamaludin, "Towards an Islamic Lifelong Learning Information System: A Visionary Model of an Islamic Learning Community", International Conference on Computing and Informatics (ICOCI), Bandung 2011.

\section{Wawancara:}

Amin, anggota Laskar Hisbah Solo, Februari 2015.

Agus Junaedi, Ketua Laskar Hisbah Solo.

Edi Lukito, Panglima Laskar Umat Islam Surakarta (LUIS), Solo, 2 Maret 2015.

Mohamad Arif, Purwosari, Solo, Februari 2015.

Syamsul Bakri, Wakil Dekan Fakultas Ushuluddin dan Dakwah Institut Agama Islam Negeri (IAIN) Surakarta, Desember 2014.

Mohamad Atif, simpatisan Gerakan Laskar Solo, Februari 2015.

Rahman, simpatisan gerakan-gerakan Islam di Solo, Semanggi, Februari 2015.

Yusuf Parmadi, salah satu jama'ah setia Abdullah Sungkar dan Sekretaris Jendral Laskar Umat Islam Surakarta (LUIS), Solo, 4 Maret 2015.

Yoyo, adik kandung Sigit Qardhawi (pendiri Tim Hisbah). 